\title{
Reflections on the Development of Overseas School Running by Higher Education Institutions of China under the Background of the "Belt and Road" Initiative
}

\author{
Hongmin Li \\ International Cooperation \& Exchange Office \\ Yunnan University of Finance and Economics, YUFE \\ Kunming, China \\ bizlynn@hotmail.com
}

\author{
Zhifei Li* \\ International Cooperation \& Exchange Office \\ Yunnan University of Finance and Economics, YUFE \\ Kunming, China \\ lizhifei1115@126.com
}

\begin{abstract}
Overseas school running is an important part of the "international development" strategy of China's educational internationalization, with greater sense of the era and practical value under the "Belt and Road" Initiative. In the paper, the development history and present situation of overseas school running of China are sorted out. An analysis is made on the prospect and significance of overseas school running in the countries and regions along the "Belt and Road" by China in association with the demand of the "Belt and Road" construction. It is pointed out that China needs to make use of the opportunity and plan the advancement as a whole based on its characteristics, thus to establish the overseas school running development approach centered on teaching staff and teaching quality and to provide better talent and intelligence support for the "Belt and Road" construction.
\end{abstract}

Keywords-the Belt and Road Initiative; opening up of education; overseas school running Introduction

Under the "Belt and Road" Initiative, China has broader space and more urgent driving force for international educational communication and cooperation. The advancement of co-construction of the "Belt and Road" has provided an opportunity for promoting regional educational opening up, exchange and integration. Educational cooperation and joint action among the countries and regions along the "Belt and Road" is not only an important part of the co-construction of the "Belt and Road", but it also provides talent support for co-construction of the "Belt and Road" [1].

As an important part of the "international development" strategy of educational internationalization, overseas school running can play a basic and leading role of education in the process of Sino-foreign communication and cooperation, playing an non-negligible role in promoting mutual cooperation and co-win between China and the countries and regions along the "Belt and Road".

*Corresponding author

\section{Present DeVelopment Situation of Overseas School RUNNING BY HIGHER EDUCATION INSTITUTIONS OF CHINA}

The practice of China in overseas school running cooperation started as early as in the 1970 s, but for a long time, it has focused on specialized cooperation among higher educational institutions as well as mutual teacher visit and joint cultivation of students with the nature of inter-school agreement basically. It is led by the foreign party and assisted by the Chinese party. For example, Nanjing University of Chinese Medicine took the lead to open TCM specialty in Portugal and Norway in 1988. Generally speaking, overseas school running was very few at that time. After joining in WTO in 2001, China realized the possibility of more overseas school running and issued the Interim Measures for the Administration of Overseas School-running Activities by Higher Educational Institutions[2] in 2002.

However, the issuance of the tentative management rules didn't play much substantial role, and the scale and quantity of China's overseas school running was still limited. In 2004, the establishment of the worldwide first Confucius College in Korea was a marking event, indicating the transformation of China's education "output" from responsive satisfaction of the world's certain demand to "international development" to join in educational globalization. It is also an important event that China's education participates in global competition of resources and layout and serves the national strategy. In the following decade, Confucius College developed rapidly with great success achieved. However, the school running tenet and content of Confucius College determine that its main role is a bridge and window to promote international education and can not really join in competition of the global educational service market; hence it can not play a decisive driving role for China's educational internationalization.

Independently or jointly establishing colleges/universities overseas is the highest level of overseas school running by higher educational institutions. It is also a strategic measure reflecting and playing the influence of education. Through 
long accumulation and exploration, China's higher educational institutions have started active attempt in this aspect in recent years. Soochow University in Laos, established in July 2011, is the first overseas university approved by the Chinese government which is an independent corporate higher educational institution registered in Laos founded by Soochow University and controlled by Soochow University. It started to enroll regular students for a bachelor's degree in 2012. In 2012, Xiamen University declared to establish a campus in Malaysia, the construction was commenced in 2014 and the first enrollment was realized in September 2015.

In December 2013, the Ministry of Education of the People's Republic of China approved Yunnan University of Finance and Economics to establish Bangkok School of Business, Yunnan University of Finance and Economics in Thailand. On April 1, 2015, the unveiling and school starting ceremony of Beijing Language and Culture University Tokyo College was held in Ikebukuro, Tokyo, and the first Japanese campus of a Chinese key university directly under the Ministry of Education welcomed the first group of Japanese students. By March 2016, five overseas school running institutions and 98 programs of China had been established overseas, distributed in 14 countries and regions. In addition, some cooperation agreements or intents are in the process of implementation. For instance, on September 9, 2015, witnessed by President Xi Jinping and Abdullah II, King of Jordan, the Ministry of Education of China and the Ministry of Higher Education and Scientific Research of Jordan signed the Framework Agreement on Cooperation in Construction of Higher Educational Institutions. According to the contents of the agreement, China University of Geosciences (Wuhan) would go to Jordan for activities in relation to running of "Sino-Jordan University", which aroused extensive social attention [3].

From the review about the process of China's cooperation practice in overseas school running we may see the historic transformation of the development of foreign communication and cooperation of education in China under the background of globalization. Presently, China has stepped from the unidirectional cooperative school running of educational "input" to the bidirectional development stage with simultaneous development of educational "input" and "output". Such transformation of development indicates the increasing growth of China's international influence in terms of education as well as the continuous improvement of China's horizon and level in terms of educational internationalization.

It is held by $\mathrm{Li}$ Xiaohong that internationalized school running has been the educational practice extensively advocated and concerned by Chinese higher educational institutions. In particular, with the development of economic globalization and regional integration as well as the promotion of educational opening up strategy in more countries and regions, worldwide educational resource sharing and flow and allocation of high-quality resources in different countries and regions have become one of the most significant characteristics of the world development of higher education in the new historical era [4]. In other words, with the rising of China as an emerging great power for education, the international society has seen increasingly great demand for China's education to participate in the talent cultivation system of educational globalization to cultivate more highquality internationalized talents for different countries and regions. Therefore, overseas school running is becoming a major trend for development of China's higher education with a broad prospect. However, we should also see that compared to the unfolding Sino-foreign cooperative school running by introducing foreign resources in China, overseas school running by China is still at a starting stage, with insufficient experience and limited quantity and scale. In particular, under the background of the "Belt and Road" construction, overseas school running by higher educational institutions is endowed with new mission and demand, with its development quality and efficiency of critical significance for educational foreign opening up and the "Belt and Road" construction.

\section{ANALYSIS OF DEMAND FOR OVERSEAS SCHOOL RUNNING}

\section{A. Service Demand}

China is facing the great opportunity in terms of overseas school running in the countries and regions along the "Belt and Road" with a broad prospect. Such countries and regions have high recognition, expectation and participation of the "Belt and Road" Initiative. With continuous deepening of the "Belt and Road" construction, the demand for various internationalized talents will definitely increase, and international education communication and cooperation will definitely become an important part of the "Belt and Road" construction. In many countries and regions along the line, the educational resources and educational construction capacity cannot meet the need of social development and there is a huge gap for various specialized talents for national construction as such countries and regions have a relatively short history of independence.

In a long time in the future, promoting domestic educational development with foreign educational resources will still be the main development strategy and thought of the countries and regions, which provides great possibility for China to have overseas school running in the region. Since the "Belt and Road" Initiative was proposed, more and more countries and regions have sent invitation to China's higher educational institutions for school running. More than ten countries and regions have already sent invitations or expressed related desire including Kyrghyzstan, Pakistan and Kazakstan. It proves that China's educational development mode and achievements have primarily won recognition of the international society. Besides, the demand of countries and regions along the "Belt and Road" for overseas school running by China is not limited to educational demand; instead, it is more of the demand for the local economic and social development and the people's life quality.

According to the present situation of regional economic development, China will establish school running programs accordingly to serve the local development, enhance integration of international resources and local resources and integrate local and regional development characteristics into the practice of school running, finally providing intelligence 
support for the local economic and social development and improvement of the local people's living standard.

\section{B. Professional Demand}

From the practical effect of establishing overseas campuses by domestic and foreign universities we can see that whether an overseas campus can soundly operate and develop is closely related to whether the university has a clear positioning of the overseas campus. Therefore, China's higher educational institutions should make scientific plans for overseas school running and have clear understanding about the positioning of overseas school running. To solve the adaptability issue for "international development" of China's higher educational institutions, we should also know about the local situation in depth from the cultural perspective to set specialties meeting the demand of local economic and social development. Under the background of the "Belt and Road" construction, such specialties as languages (including Chinese and non-general language specialties for countries and regions along the line), culture and social science and occupational application have been in urgent need for development of overseas school running.

Firstly, the number of official languages is more than 40 in the five regions (Middle Asia, Southeast Asia, South Asia, West Asia and Eastern Africa) covered by the "Belt and Road", and the issue of language communication with the countries and regions along the line is one of the critical factors in relation to whether the "Belt and Road" Initiative will be successful. Therefore, the demand for language specialty is the foundation for development of overseas school running under the background of the "Belt and Road" construction.

In 2016, it was pointed out in the Several Comments on Educational Foreign Opening up Work in the New Era issued by the General Office of the CPC Central Committee and the General Office of the State Council to strengthen mutual help in Chinese promotion and learning of non-general languages and promote language interconnection with countries and regions of the world. Chinese is not only one of the languages for cooperation and communication of China with the countries and regions along the "Belt and Road", but it is also an important security for China's soft strength and international competitiveness. Therefore, the development effect of Chinese international education impacts the in-depth operation and implementation of the "Belt and Road" construction to a great extent. During the development of overseas school running, continuous enhancement of Chinese international education and promotion is helpful for students of the countries and regions along the line to better understand the language and culture of China and for promoting the communication and cooperation of the countries and regions along the line with China, finally realizing the win-win situation of reciprocity.

Secondly, communication of the popular feelings is the social root of the "Belt and Road" construction. Inheriting and carrying forward the friendly cooperation spirit of the Silk Road and extensively carrying out culture exchange, academic communication, talent exchange and cooperation, media cooperation, youth and women communication and volunteer service lays a foundation in terms of the people's will for deepening bilateral and multilateral cooperation. It is proposed in the Several Comments on Educational Foreign Opening up Work in the New Era to enrich Sino-foreign culture exchange and promote communication of popular feelings. Hence the specialty of culture and social science has become one of the specialty demand points for overseas school running development under the "Belt and Road" Initiative. Presently, the specialties opened by the existing five overseas school running institutions and 98 programs are mainly Chinese language and literature, Chinese medicine and pharmacy, Chinese acupuncture, traditional Chinese wushu, preschool and special education and cooking art and nutrition. Such specialties urgently needed by the countries and regions along the line as law, management and economics are in lack or account for a small proportion. Under the background of the "Belt and Road" construction, the specialty of culture and social science is still an important point to be tackled for educational cooperation and culture exchange between China and the countries and regions along the line.

And thirdly, with the demand for occupational application talents for the "Belt and Road" construction taken into consideration, application specialty has been a field of specialty that must be emphasized in overseas school running. For years vocational education in China has been paid insufficient attention with a low social status.

In the process of promoting educational internationalization, the level of cooperation and communication in vocational education is low and the quality cannot be assured. Under the background of the "Belt and Road" construction, the demand for occupational application specialty provides powerful support for enhancing the quality of occupational application specialty in the process of overseas school running. We should bring the characteristics and advantages of economic development into full play, comprehensively consider the strategic demand of the countries and regions along the line and strengthen the setting and development of occupational application specialty in overseas school running in order to provide specialized talents for bilateral and even multilateral reciprocal cooperation and communication. For example, in terms of cultivation of railway specialized talents, we can bring the development characteristics of railway and rail transit in China into play and set corresponding occupational application specialty to boost the railway occupational talent development and social development of the countries and regions along the line. In a word, under the background of the "Belt and Road" construction, overseas school running is endowed with the new task of talent cultivation to cultivate innovation, application and language oriented high-end talents of international horizon. 


\section{DEVELOPMENT STRATEGY FOR OVERSEAS SCHOOL RUNNING}

A. Planning overseas School Running Development as a Whole in Response to the Need of National and Local Economic and Social Development

Overseas school running is a major educational project. China is still at an exploring stage in terms of overseas school running and some mature regulatory management provisions and operable directive policy documents are to be issued. More importantly, the country needs to focus on globalized development and the future world layout to formulate a general development plan for overseas school running as soon as possible and to promote work in various aspects down to earth based on the plan. Driven by the "Belt and Road" construction, higher educational institutions of China are having increasingly frequent cooperation and communication with the higher educational institutions of the countries and regions along the line. But in terms of the present situation, China's higher educational institutions face many difficulties in independent school running overseas due to limitation by such factors as their own development strength, talent reserve, operating mechanism and management system.

Therefore, overseas school running needs to be considered as a national strategy presently with the sense of urgency for the era instead of free choice, free competition and unordered spillover of the domestic educational resources and powers. Following the printing and issuance of the Action Pushing forward the Joint Construction of "the Belt \& Road", the Ministry of Education of the People's Republic of China has successively signed memorandum of cooperation with several provinces, cities and autonomous regions, which shows the ordered nature and top-level driving effect of educational internationalization development in China. Presently we need to soundly implement such cooperation actions and establish development plans with strategic thoughts.

Each province and autonomous region should make active use of the location advantages in historical origin, crossboundary nationality, culture similarity and convenient language communication with the countries and regions along the line in terms of social culture as well as the cooperation advantages in frequent nongovernmental communication on border, smooth transport and logistics, active border trade and overall industrial cooperation to integrate educational resources, thus to shoulder the national task of overseas school running in the countries and regions along the line. It is of great significance for expanding the international influence of China as well as promoting educational internationalization and overall development of the "Belt and Road" construction.

B. Based on the Development Requirement of the Specialty Subjects, Make Full Efforts to Create an International Faculty with Reasonable Structure, High Level and Excellent Quality

A reasonable and relatively stable faculty is the power source for sustainable development of overseas schools. In order to meet the actual needs of the teaching management of overseas schools, the plan should combine the specialties of the subjects, the characteristics of the students and the scale of the school. Measures should be taken to prevent the formation of such situation that the faculty of the overseas school is to digest or relocate the redundant personnel from their parent university and prevent high mobility of teaching managers. Otherwise, it will seriously damage the management efficiency of the school.

\section{Establishing Teaching Quality Assurance Mechanism for Overseas School Running}

High-quality education and teaching is the lifeline for overseas school running. Presently, higher educational institutions of China need to be further improved in terms of school running positioning for both their school running institutions and programs. They should serve the local development while publicizing Chinese culture and should never ignore the adaptability of specialties. To soundly promote overseas school running, the local government and some schools should also avoid blind "international development" for overseas school running to pursue "face project" and "government performance project".

China's higher educational institutions have a short history in overseas school running with insufficient experience and are in urgent need of strategic arrangement and uniform planning on the national level. In order to borrow the experience of developed countries and regions for reference, China's government needs to establish an independent quality assurance institution similar to QAA of Britain to be responsible for external quality assurance for multinational higher education. At the same time, third parties should be organized or authorized to assess the level and educational quality of overseas school running and publicize the assessment result to the society. China's authorities in charge of education should actively have cooperation with overseas diploma certification organizing institutions to strengthen diploma certification for overseas school running, thus to secure the diploma quality and international reputation of overseas school running by China.

\section{To Make Full Use of the Functions of the Cultural Dissemination of the Overseas School and Build a Regional International Cultural Hub}

To vigorously implement the cultural exchange mechanism that lays importance to both "import" and "export"; to expand the cultural exchange channels between domestic universities and foreign universities, scientific research institutions, enterprises and government agencies, etc. and build a stable international cultural exchange hub by taking the overseas school as an exchange platform; to cultivate the students study in the overseas school to be international cultural exchange ambassadors by applying an international education mode, so as to fully improve the school's image in the education receiving countries and regions, and even in the word and help the export of the educational characteristics, culture and national soft power. 


\section{ACKNOWLEDGMENT}

Upon the completion of this paper, I would like to show my deepest gratitude to my colleagues and all those who, directly or indirectly, have given me their valuable advice and generous support to help me work out problems during the course of the present paper.

\section{REFERENCES}

[1] Ministry of Education of the People's Republic of China, Action Pushing forward the Joint Construction of "the Belt \& Road", July 2016.
[2] Ministry of Education of the People's Republic of China, Interim Measures for the Administration of Overseas School-running Activities by Colleges and Universities, December 2002.

[3] Chen Yinghui, "The Development and Policy Orientation of ChineseForeign Operation in Running Schools and Overseas School Running”, 2016.

[4] Li Xiaohong, "Thoughts on the Internationalization of Chinese Higher Education", Journal of World Education, 2013(2).

[5] Liu Qiang, Jing Xiaoli, "Research on the Development of China's International Education: from the Perspective of Some Developed Countries", International and Comparative Education, 2016(10).

[6] Yan Xiao, "Motivation Analysis and Suggestions of Chinese Universities to Go Abroad to Run Schools", Journal of Higher Education Management, May 2016, vol. 10, pp.66-68. 